\title{
Historie alternatywne Konrada T. Lewandowskiego
}

W opublikowanym na łamach "Czytania Literatury" (nr 6) artykule pisałam o połączeniu kryminału z historią w kryminale retro. Autorem, którego twórczość dostarczyła przykładów eksperymentów z historią dokonywanych w ramach tego gatunku, był Konrad T. Lewandowski.

W niniejszym tekście kontynuować będę rozważania na temat prozy tego autora, tym razem skupiając się nad sposobami kreowania przez niego polskiej „historii niebyłej” w nurcie literatury określanym mianem historii alternatywnych. Przedmiotem badawczej refleksji staną się: Królowa Joanna $d^{\prime} A r c$ - utwór zdefiniowany przez autora w podtytule jako „powieść fantastyczna”, przez innych jako "historia alternatywna"1 - przygodowa trylogia o losach Bursztynowego Królestwa² oraz fantastyczna powieść steampunkowa pod zagadkowym tytułem Orzeł bielszy niż gołębica ${ }^{3}$.

* Uniwersytet Szczeciński, Wydział Filologiczny, Instytut Polonistyki, Kulturoznawstwa i Dziennikarstwa, Zakład Literatury Polskiej XX i XXI wieku, e-mail: ewa.tierling@ usz.edu.pl.

${ }^{1}$ K.T. Lewandowski, Królowa Joanna d'Arc. Powiesśc fantastyczna, Warszawa 2000. Jako historię alternatywną sklasyfikował tę powieść Paweł Dunin-Wąsowicz w przeprowadzonym z K.T. Lewandowskim wywiadzie. Zob. K.T Lewandowski, Rzemieślnik metafizyk [rozm. P. Dunin-Wąsowicz], [online] http://ksiazki.onet.pl/rzemneslnik-metafizyk/x078z (dostęp: 25.08.2016). W 2014 roku Lewandowski wznowił tę powieść, wydając ją razem z Wysłanniczka bogini. Znamienny wspólny tytuł oraz seria książek wydawanych przez Narodowe Centrum Kultury - zob. K.T. Lewandowski, Utopie, Warszawa 2014, seria „Zwrotnice Czasu”, t. 13.

${ }^{2}$ Cytaty i odsyłacze z powieści oznaczam umieszczonym w nawiasie skrótem literowym wraz z podaniem numeru strony, z której pochodzi fragment.

K.T. Lewandowski, Bursztynowe Królestwo. Powieść przygodowa, Wrocław 2009; tenże, Afgański Zeus. Powieść przygodowa, Wrocław 2011 - (A); tenże, Bohaterowie się odradzają. Powieść przygodowa, Wrocław 2012 - (Bo).

${ }^{3}$ K.T. Lewandowski, Orzeł bielszy niż gołębica (powieść fantastyczna w konwencji steampunk), Warszawa 2013. Cytaty oznaczam umieszczonym w nawiasie skrótem literowym (O) wraz z podaniem numeru strony, z której pochodzi fragment. Określenie „historia niebyła” pochodzi od tytułu książki Alexandra Demandta (Historia niebyła: Co by było gdyby, przeł. M. Skalska, Warszawa 1999). 
Sformułowanie celów badawczych niniejszego tekstu poprzedzić musi przypomnienie specyfiki nurtu/gatunku $\mathrm{w}$ literaturze określanego mianem "historii alternatywnych". Na temat zainteresowania "historią niebyłą" w historiografii i literaturze pisałam już w innym miejscu ${ }^{4}$. Chcąc zatem uniknąć szczegółowego referowania wcześniejszych ustaleń, powtarzania wniosków, ograniczę się jedynie do najważniejszych konstatacji.

„Historia niebyła” to gatunek/nurt prozy fikcjonalnej, który „twórczo rozwija spekulacje probablistyczne, odpowiadając na pytanie «co by było,

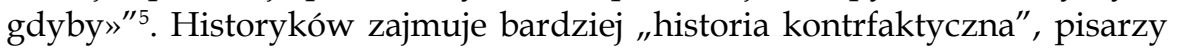
- „historia alternatywna”. Różnice między nimi analizował Paweł Tomczok, który stwierdzał, iż historycy poszukują swoistych punktów zwrotnych w historii i podejmują dywagacje nad tym, co by się stało, gdyby dane wydarzenie przebiegało inaczej, niż miało to miejsce w rzeczywistości. Tworzą zatem "historie kontrfaktyczne", w których spekulacje dotyczą w większym stopniu zwrotu dziejowego zwanego po angielsku point of divergence niż potencjalnej, alternatywnej historii, jaka mogłaby mieć miejsce po takim w rzeczywistości „niebyłym” wydarzeniu. Literatura natomiast chętniej zajmuje się "historią alternatywną" - tym, co jest skutkiem przestawienia "zwrotnicy czasu", nie zaś samym wydarzeniem, wyborem czy decyzją bohatera historycznego ${ }^{7}$.

Punkt odniesienia dla moich rozważań na temat historii alternatywnych tworzonych przez Konrada T. Lewandowskiego stanowi definicja „,historii alternatywnej" autorstwa Tomasza Węcławiaka:

Historia alternatywna - nurt literatury fantastycznej (przede wszystkim fantastycznonaukowej), który ukazuje alternatywny wobec znanego nam przebieg procesu dziejowego. W świecie o zmienionej historii osadzona jest akcja utworu, która może - ale nie musi - być związana z odmienionym

${ }^{4}$ E. Tierling-Śledź, Powstanie styczniowe, którego nie było, czyli historia alternatywna w powieści Adama Przechrzty "Gambit Wielopolskiego", [w:] Dyskurs powstańczy w kulturze polskiej, red. D. Dąbrowska, Szczecin 2015, s.129-146.

${ }^{5}$ Historia alternatywna, [w:] Stownik rodzajów i gatunków literackich, red. G. Gazda, Warszawa 2012, s. 380.

${ }^{6}$ Oba stanowią warianty "historii niebyłej”. Definicja słownikowa definiuje „historię niebyłą" jako gatunek, w swoich wcześniejszych pracach skłaniałam się ku ujmowaniu alternatywy historycznej jako nurtu w literaturze.

${ }^{7}$ Tomczok stwierdzał, iż: „W historiach alternatywnych [...] samo wydarzenie należy do mniej lub bardziej odległej historii, zaś utwór dotyczy dalszych dziejów alternatywnej rzeczywistości - moment dziejowego zwrotu będzie raczej wspominany niż przedstawiany: uwaga koncentrować się będzie bardziej na konsekwencjach tego zwrotu, niż opracowaniu jego możliwości. [...] Historia kontrfaktyczna [podkr. E.T.Ś.] dużo mocniej niż historie alternatywne wiąże swoje badania z miejscem historycznego zwrotu - zwykle analizuje możliwość innej decyzji, innego kontekstu, zdarzenia innego niż to, które znajduje poświadczenie w uznanych źródłach, zatem jest «faktem»" - P. Tomczok, Opowiadanie historii Polski - całkiem inaczej, „,artPapier" 2009, nr 14, [online] http://artpapier.com/index.php?page=artykul\&wydanie=88\&artykul=2034 (dostęp: 5.08.2016). 
przebiegiem wydarzeń historycznych. Funkcja alternatywnej historii może być ograniczona jedynie do niezwykłego tła fabuły, wprowadzającego element fantastyczny. Odmienny bieg historii zapoczątkowany jest fikcyjnym wydarzeniem, najczęściej innym od znanego nam, rozwiązaniem trudnej, znanej z historii sytuacji, ale także ingerencją bohaterów, noszącą znamiona fantastyki, na przykład przemieszczeniem w czasie lub pomiędzy równoległymi światami. Wydarzenie to może być w utworze pominięte, podobnie jak dokładny przebieg historii, aż do momentu, w którym dzieje się akcja utworu, ale zawsze świat przedstawiony jest wystarczająco odmienny od znanego, a czytelnik otrzymuje odpowiednią ilość informacji, by zorientować się, że ma do czynienia ze światem przedstawionym o alternatywnej przeszłości. Choć historia alternatywna stwarza ogromne możliwości analizowania i badania mechanizmów dziejowych i społecznych, często traktowana jest przez autorów instrumentalnie, jako pretekst i tło przygodowej fabuły, więc potencjał intelektualny w niej zawarty bywa niewykorzystany ${ }^{8}$.

Z powyższych rozważań genologicznych wynika problem perspektywy poznawczej w interpretowaniu "historii alternatywnych”. Pierwszą płaszczyzną odniesienia jest historia, drugą - literatura. "Historie alternatywne" stanowią typ literatury silnie zideologizowany, zawierają zawsze pewną historiozofię pisarza. Z reguły krytycyzm autora dotyczy zarówno faktografii historycznej - wydarzeń, które autor poddaje swoistemu unieważnieniu, pokazując ich możliwą alternatywę - jak i możliwości historii jako nauki ${ }^{9}$. Postawa krytyczna nie dotyczy wtedy jedynie weryfikacji faktografii i źródeł historycznych, a więc dotarcia do prawdy historycznej. Dociekania te włączają się we współczesną dyskusję na temat statusu filozoficznego tejże prawdy. Należałoby zatem przyjrzeć się sposobom „użytkowania historii” przez Lewandowskiego oraz celowości „odkształceń historycznych" dokonywanych przez niego w różnych gatunkowo tekstach. To zadanie łączy się ściśle z namysłem badawczym nad czymś, co nazwałabym "literackością dzieła”.

Historia alternatywna - jak zostało powiedziane - stanowi odmianę literatury fantastycznej, przy czym przez fantastykę rozumieć tu należy typ fikcji, a nie gatunek literacki. Czasami bywa umieszczana „w obrębie tzw. koncepcji światów równoległych". Bywa, iż alternatywa historyczna staje się "pretekstem narracji postmodernistycznych" ${ }^{10}$, literatury wysokoartystycznej. Częściej jednak - jak w przypadku analizowanego w poprzednim artykule „kryminału retro" - historia po śmierci wielkich narracji wraca do literatury w swej alternatywnej odmianie poprzez małżeństwo z literaturą

\footnotetext{
${ }^{8}$ T. Węcławiak, Historia historii nierówna - kilka uwag o definicji historii alternatywnej, „Podteksty. Czasopismo kulturalno-naukowe" 2007, nr 4, [online] http://podteksty.amu.edu.pl/ podteksty/?action=dynamic\&nr=11\&dzial=4\&id=254 (dostęp: 5.08.2016).

${ }^{9}$ Szerzej na ten temat zob. Historia alternatywna, [w:] Słownik rodzajów..., s. 385-386.

${ }^{10}$ Tamże, s. 381.
} 
popularną. Można zatem oczywiście wymienione wyżej teksty Lewandowskiego wartościować „z pomocą kryteriów stosowanych wobec różnych modeli literatury wysokoartystycznej"11 (na przykład poprzez odniesienie do reguł powieści historycznej w jej różnorodnych odmianach). Kusić może doszukiwanie się w nich postmodernistycznych gier i eksperymentów. Uznając je jednak za swoiste hybrydy literatury popularnej, uważam, że można, czy wręcz - należy, interpretować i wartościować te utwory - jak określała to Maria Bujnicka - „immanentnie, tj. ze względu na spełnienie celów, do których owe teksty zmierzają"12. Taki sposób badawczego oglądu literatury popularnej ma swoją tradycję i pozwala uniknąć nieporozumień interpretacyjnych, wyznacza odpowiedni repertuar problemów badawczych, którymi warto się zająć.

Najważniejsze pytania, które nasuwają się podczas lektury książek autora Bursztynowego Królestwa, to: jakie oczekiwania one zaspakajają? Kto jest ich projektowanym odbiorcą? Jakie pożytki mogą wynikać z zajmowania się historią alternatywną $\mathrm{w}$ tej odmianie literatury?

\section{Alternatywne „dawno, dawno temu"}

Jak zostało powiedziane, Konrad T. Lewandowski swoje powieści zaopatrzył genologicznymi sygnaturami w podtytułach. Ma to określone znaczenie przy pierwszym zetknięciu odbiorcy z tekstem. Podtytuł taki wywołuje pewne oczekiwania związane z deklarowaną poetyką, ułatwia wstępne rozpoznania konwencji i wyznacza ścieżkę interpretacyjną. Tak dzieje się w przypadku wydania w serii „Biblioteka fantastyki” Królowej Joanny d'Arc jako powieści fantastycznej. I rzeczywiście - spotykamy się tu ze specyficzną opowieścią o historii, w której obok postaci historycznych, takich jak królowa Jadwiga, Władysław Jagiełło, biskup Zbigniew Oleśnicki czy tytułowa Joanna d'Arc, pojawia się fantastyczna Dziewica Moru, a na kształt polskiej historii wpływ może mieć także czarownica i jej czarna antyrelikwia. Deklarowana fantastyka nie tylko ogranicza rozliczanie autora ze zgodności z faktografią historyczną, ale unieważnia zarzuty braku realistycznego prawdopodobieństwa może nie wszystkich elementów świata przedstawionego, ale z pewnością realistycznej "logiki dziejów”. Historia wpisana zostaje zarówno w porządek metafizyczny, jak i fantastyczno-baśniowy.

Odautorskie określenie dzieł Bursztynowe Królestwo, Afgański Zeus oraz Bohaterowie się odradzają mianem powieści przygodowych uruchamia czytelnicze nadzieje przede wszystkim na obecność w utworze wartkiej akcji, nie zaś spójnej i logicznej ilustracji określonych wydarzeń historycznych. Także określenie "powieść steampunkowa” sugeruje przede wszystkim narrację o wynalazkach „epoki pary”. O ile jednak określenie konwencji „odwraca”

${ }^{11}$ M. Bujnicka, Sporne i bezsporne problemy literatury popularnej. Odpowiedź prof. Annie Martuszewskiej, [w:] Literatura i kultura popularna. VI, red. T. Żabski, Wrocław 1997, s. $26-27$.

${ }^{12}$ Tamże, s. 27. 
uwagę od przekazu historycznego, już od pierwszych stron powieści okazuje się, że mamy do czynienia z mieszaniną gatunkową będącą realizacją połączenia każdej z wymienionych konwencji z powieścią historyczną i historią alternatywną, natomiast przeszłość staje się głównym przedmiotem istotnych operacji sensotwórczych.

Szczególnie wtedy, gdy historia alternatywna w powieściach Lewandowskiego łączy się z gatunkami literackimi pokrewnymi baśni lub realizującymi normy gatunkowe powieści przygodowej, jej funkcja może mieć charakter typowo ludyczny. Stopień znajomości historii zwiększa jednak skuteczność literackiej gry z przeszłością, pogłębia możliwość odcyfrowania szyfrów historycznej alternatywy oraz sprzyja czytelniczej satysfakcji. Hipotetycznie po Królowa Joannę d'Arc może sięgnąć odbiorca zupełnie nieorientujący się w szczegółach biografii Dziewicy Orleańskiej, którego lektura ograniczy się do czytania tego tekstu jako opowieści fantastycznej na kanwie historycznej. Pakt czytelniczy historii alternatywnej bazuje wszakże na znajomości przebiegu realnych wydarzeń i możliwości deszyfracji historycznej alternatywy. Czytelnik znający polskie losy odkryje, pojmie więcej i być może będzie bawił się rozwiązywaniem historycznej szarady i ustalaniem faktograficznego prawdopodobieństwa alternatywnej historii. Taki czytelnik jest - w moim przekonaniu - głównym odbiorcą książek tego autora.

Podobnie jak $w$ pozostałych wymienionych wyżej powieściach także w Królowej Joannie d'Arc historia przebiega odmiennie od znanego nam ze szkolnej edukacji biegu dziejów. Joanna d'Arc po udzieleniu wsparcia francuskiemu królowi przybywa do Polski, a jej powieściowe życie nie kończy się śmiercią na stosie. Królowa Jadwiga nie umiera młodo $\mathrm{w}$ trakcie połogu, ale panuje ze swym mężem przez czterdzieści pięć lat, rządząc zdecydowanie i roztropnie. Syn Jadwigi i Jagiełły Władysław III (bynajmniej nie historyczny Warneńczyk) już po śmierci ojca i matki zasiada nie tylko na tronie polskim, ale jeszcze wcześniej zostaje królem Czech. Tylko czytelnik o dużych kompetencjach historycznych zorientuje się w polityce, którą prowadzą polska królowa czy cesarz niemiecki, zrozumie sens poczynań dostojników kościelnych. Tenże odbiorca sporządzi „protokół historycznych rozbieżności", rozezna się w odmienności szczegółów dziejów husytyzmu oraz militarnych zmaganiach, które w rzeczywistości nie miały miejsca ${ }^{13}$.

Znający przebieg dawnych wydarzeń odbiorca powinien jednak zadać przede wszystkim pytanie dotyczące celowości konstrukcji tej historycznej

${ }^{13}$ Dodajmy przykładowo także, iż odbiorca powieści Bohaterowie się odradzają dowie się, że Józef Piłsudski i Roman Dmowski, razem wybierając się do Japonii, uczestniczą w wydarzeniach nieznanych nam $\mathrm{z}$ podręczników historii. $\mathrm{W}$ kształtowaniu sylwetek obu postaci autor korzysta $\mathrm{z}$ pewnych stereotypów. Piłsudski to zatem socjalista, były zesłaniec, który umie posługiwać się bronią, ale także przez dzieci jednej z bohaterek jest nazywany... dziadkiem i - niejako występując $\mathrm{w}$ tej roli - opowiada im bajki na dobranoc. Zważywszy na to, iż akcja powieści rozgrywa się w 1904 roku, ten ostatni element charakterystyki bohatera budzić może uśmiech czytelnika, szczególnie gdy narrator komentuje: „Pół żartem, pół serio wyrzekał czasem, cóż to będzie, jeśli ten tytuł przylgnie do niego na stałe" (Bo, 43). 
alternatywy ${ }^{14}$. Punktem zwrotnym prezentowanej wizji średniowiecza jest u Lewandowskiego brak bitwy pod Grunwaldem, której zapobiega królowa Jadwiga, stając przed wojskami wroga i udowadniając, że chcą one walczyć ze świętą, a nie z poganami. W konsekwencji Jagiełło, zamiast walczyć, zajmuje się płodzeniem syna. Joanna d'Arc zostaje tegoż syna kochanką. Oboje muszą zrezygnować ze swojej miłości. Grzeszna już, a nie święta, Joanna zamknięta w klasztorze rodzi dziecko. Król może panować dalej.

W wielkiej powieści historycznej historia miłosna stawała się literackim nośnikiem narracji o przeszłości, wybór między prywatnym szczęściem a powinnością wobec narodu prowadził nierzadko do osobistej tragedii. Jednak czemu ma tu służyć rozpoznana konwencja? Czy Lewandowski prowokuje, posługuje się strategią skandalu, gdy „jego” Dziewica Orleańska traci w Polsce swoje dziewictwo? Wnioski nie są jednoznaczne.

Bez bitwy pod Grunwaldem alternatywna Polska jest w powieści Lewandowskiego mocarstwem skutecznie opierającym się najeźdźcom. Historyczna bitwa pod Grunwaldem była - dziś już w powszechnej opinii - niewykorzystanym politycznie zwycięstwem, które stało się wszakże mitem polskiej militarnej potęgi, mitem polskiego zwycięstwa. Ten mit okazuje się ważniejszy niż prawda historyczna, posiada większą siłę oddziaływania - zdaje się mówić Lewandowski. Po drugie: jaki jest sens fundowania patriotyzmu na zwycięstwach, które w rzeczywistości nie miały tak wielkiego znaczenia jak ich historyczne alternatywy?

Dlaczego jednak młody Władysław III i Joanna d'Arc muszą zrezygnować z miłości? Dlaczego francuska bohaterka nie mogłaby zostać polską królową, choćby w historycznej alternatywie dziejów? W świecie przedstawionym powieści świętość utożsamiana $\mathrm{z}$ dziewiczą czystością Joanny d'Arc i jej zmysł taktyczny miały zapewnić zwycięstwo tym, po których stronie walczyła. $Z$ jednej strony przekonanie to znajduje swoją weryfikację - wojska faktycznie zwyciężają, gdy Polacy po swojej stronie mają świętą. Z drugiej natomiast - (czy nie w większym stopniu?) ukazane jest ono jako mit, przedmiot ludowej wiary, sąd wyrażany niezależnie od rzeczywistości, ponieważ w pewnym momencie Joanna grzeszy ziemską, cielesną miłością, a wojsko nadal jest przekonane o duchowej sile jej dziewictwa. W micie nie mogło być zatem miejsca na ziemską miłość, cielesność Joanny. Skoro utraciła dziewictwo dla dobra mitu, musi zniknąć z planu historii. Mit musiał być ocalony nie tylko „ze względu” na bohaterów powieści, ale także - jej odbiorcę. Mogła zatem Joanna nie spłonąć na stosie, mogła zgrzeszyć ziemską miłością, ale dla tej miłości (o której wie odbiorca powieści, ale nie wie lud i rycerstwo idące do boju) trzeba było w planie powieści znaleźć usprawiedliwienie i możliwość odpokutowania. Wymagało też tego domknięcie fabularne wątku, zatrzymanie alternatywnej sekwencji wydarzeń oraz - być może - jednak autorska rezygnacja ze strategii skandalu.

\footnotetext{
${ }^{14}$ Bawiąc się, wyjdzie jednocześnie poza krąg ludycznego odbioru tekstu.
} 
W „historii alternatywnej” przedstawionej w powieści Lewandowskiego odmienny przebieg wydarzeń ulegnie zatrzymaniu/wyczerpaniu, skoro pomimo przestawienia „zwrotnicy czasu” Joanna nie zostanie polską królową, a wszystko powraca na swoje miejsce. Alternatywny wiek XV przepada „jak kamień w wodę", wszystko wydarza się jak w baśni „dawno, dawno temu", więc nieprawdziwie.

\section{Alternatywne „za górami, za lasami"}

Z baśniowym i zarazem fantastyczno-naukowym rodowodem historii niebyłej mamy do czynienia także, gdy alternatywa dziejowa rozgrywa się „za górami, za lasami". W stosunku do wyżej ukazanej historii alternatywnej rozgrywającej się w XV wieku zachodzi jednak pewna różnica. Otóż w przypadku trylogii o losach Bursztynowego Królestwa wszechwiedzący narrator sugeruje, iż - jak w palimpseście - spoza rzeczywistej, znanej nam dwudziestowiecznej historii prześwituje jakby jakaś głębsza warstwa, jaką jest jej alternatywa historyczna. W tym przypadku autor sięga nie tyle do faktów, których nie było, ale przywołuje wydarzenia, które być może miały miejsce, ale brak jest ich poświadczenia w źródłach. Powstałe pod koniec XIX wieku Bursztynowe Królestwo - wspólne państwo Polaków (poszukiwaczy złota i zbiegów z Sybiru) oraz Chińczyków z gminy Tajpingów - pod panowaniem Władysława $V$, wybranego elekcyjnie Chińczyka, trwało krótko i miało zaginąc „ „w mrokach dziejów”15. Przedstawione w powieści konsekwencje tej zapomnianej historii (nieudokumentowanej i tak niesamowitej, że zyskującej znamiona alternatywy historycznej) zostają przy tym przedstawione tak, jakby i wydarzenia, i ich skutki istniały naprawdę. Oto przykład.

W powieści Bohaterowie się odradzaja dokonano dla potrzeb militarnych adaptacji wynalazku braci Wright ${ }^{16}$. Z powszechnego zastosowania prototypu przez Polaków nic nie wyszło. Został on wykorzystany w jednej unaocznionej $\mathrm{w}$ powieści bitwie. $\mathrm{W}$ oficjalnej historii Syjamu odnotowano zatem, iż pierwszy samolot został do tego kraju sprowadzony dopiero w 1911 roku. Jednak sześć lat później miało dojść do tego, co określiłabym mianem "przebłysku” w realnych dziejach historycznej alternatywy. Jak informuje narrator:

gdy Królestwo Syjamu przystąpiło do wojny światowej przeciwko Niemcom, z głębi indochińskiej dżungli na front zachodni przysłano kolumnę

${ }^{15}$ Informacje na ten temat podaję za: M. Smętek, Awanturnik fandomu, czyli biografia Przewodasa, [online] http://przewodas.pl/biografia-przewodasa/ (dostęp: 13.11.2017).

${ }^{16}$ Opis wynalazku oraz dokonana próba wykorzystania prototypu samolotu do celów bojowych budzi skojarzenia z rzeczywiście mającymi miejsce wcześniejszymi od Wrightów doświadczeniami Clémenta Adera i zapewne działania tego pioniera awiacji zainspirowały autora. Tyle że Francuz eksperymentował z silnikiem parowym, a dopiero bracia Wright zastosowali silnik spalinowy, który też w motolatawcach bojowych starają się wykorzystać "polscy Chińczycy”. 
transportową na słoniach oraz ku zaskoczeniu przyjaciół i wrogów dziewięćdziesięciu pięciu doskonale wyszkolonych pilotów (Bo, 354) $)^{17}$.

Skąd mieliby się wziąć wyszkoleni piloci? Właśnie z czasów i okoliczności, o których niewiele wiadomo. Między rzeczywistą historią a jej historyczną alternatywą w jej palimpsestowym współistnieniu zachodzi sprzężenie zwrotne. Rzeczywista historia uprawdopodabnia historię alternatywną, ale sama staje się zrozumiała, jeśli właśnie w alternatywnym świecie zaczniemy doszukiwać się praprzyczyn, logiki niewyjaśnionych do tej pory faktów historycznych znanych z podręczników. Przyjrzyjmy się obu aspektom tej relacji.

Wyjaśnię na początek pierwszą z wymienionych sytuacji. Trylogia o dziejach Bursztynowego Królestwa została napisana w konwencji powieści przygodowej. Podróże, porwania, nagłe zwroty akcji, perypetie bohaterów mające charakter przysłowiowych "awantur arabskich" sprzężone zostają jednak zawsze $\mathrm{z}$ realną historią, nabierając realistycznego i historycznego prawdopodobieństwa we wszystkich tomach. Powstanie bokserów, wojna rosyjsko-japońska - to historyczne punkty odniesienia. Fakty i wydarzenia są albo zreferowane przez narratora, poddane eksplikacji w rozmowach i dyskusjach bohaterów, albo - jak w przypadku bitwy pod Mukdenem czy odwrotu Rosjan po przegranej wojnie - unaoczniane w całej swej dramatyczności na kartach utworu. Tak przywołana w powieści historia uwiarygodnia także alternatywę historyczną.

Z drugim aspektem relacji historia - jej alternatywny przebieg mamy do czynienia szczególnie $\mathrm{w}$ ostatnim tomie zatytułowanym Bohaterowie sie odradzają. Autor sugeruje, iż na wybuch i przebieg rewolucji 1905 roku mogły mieć wpływ polskie spiski i plany będące skutkiem dalekowschodnich wojaży Romana Dmowskiego i Józefa Piłsudskiego. Jedynie znający polską historię odbiorca wytropi, iż Piłsudski i Dmowski w 1904 roku naprawdę przybyli do Japonii, a realnym skutkiem ich rozmów było rzeczywiście zakładanie przez Japończyków osobnych obozów jenieckich dla Polaków, ale... czy coś więcej z tej podróży wynikało? ${ }^{18}$ Uzasadnienie, dlaczego historia nie odnotowuje pozostałych skutków politycznej gry obu panów, autor włożył w usta powieściowego Józefa Piłsudskiego. Kiedy jeden z bohaterów powieści wyraża żal, iż działania Polaków planowane przez Piłsudskiego i Dmowskiego mogą pozostać niezauważone: „Czeka nas los Konrada Wallenroda” (Bo, 141), przyszły naczelnik państwa ripostuje:

- Mój panie, albo chwała, albo skuteczność! - uciął Piłsudski. - Jeśli Japończycy mają wygrać tę wojnę, a my potem mieć z tego jakąś korzyść,

${ }^{17}$ Gdyby nie te słonie na froncie zachodnim, czyli w Europie, uwierzylibyśmy może w wyszkolonych syjamskich pilotów.

${ }_{18} \mathrm{O}$ wyprawie Piłsudskiego do Japonii zob. T. Filipowicz, Józef Piłsudski w Japonii w 1904 roku, "Świat" 1934, nr 11, [online] http://pilsudski.org/archiwa/dokument.php?nrar=701\&nrzesp=1\&sygn=56\&handle=701.180/1901 (dostęp: 13.06.2017). 
to musimy pogodzić się z faktem, że o nas i o tym, cośmy tu w Tokio zdziałali, po wiek wieków będą wypisywać dyrdymały w książkach do historii (Bo, 141).

Czy nie należałoby dopatrywać się tu historycznego żartu, prowokacji wobec odbiorcy, kpiny z polskiej megalomanii, że za każdym historycznym zwrotem i przewrotem kryć się musi polska inwencja i/bądź geniusz polskiej myśli? ${ }^{19}$ A może - jak pisał Tomczok - jest wręcz przeciwnie:

Historia kontrfaktyczna ujawnia zatem różne kompleksy i bolączki, ale też marzenia o odgrywaniu innej roli w dziejach Europy. Funkcja alternatyw będzie zatem miała także charakter kompensacyjny - odpowiada na marginalność naszej historii, na częste „wyrzucenie poza dzieje”20.

Powyższe stwierdzenie Tomczoka z powodzeniem można odnieść także do alternatywy historycznej Lewandowskiego, kreowanej w omawianej trylogii. Humor przejawiający się w stereotypowym przedstawianiu bohaterów, czego przykładem może być dziarski, energiczny Piłsudski mimo młodego wieku przez dzieci nazywany dziadkiem (szerzej zob. przypis 13), czy lekka ironia, jak w powyższej scenie z dialogiem o Konradzie Wallenrodzie, osłabiają patos pojawiający się w powieści w opisach heroicznej walki i śmierci za Polskę na krańcach świata. Autor „nie mruga do czytelnika”, gdy pokazuje ciąg podjętej tym razem na Dalekim Wchodzie walki "za wolność naszą i waszą", gra na emocjach, wywołuje wzruszenia, gdy ukazuje wielokrotnie bohaterską śmierć w walce o wolność i honor.

Wypowiedź narratora w zakończeniu ostatniego tomu trylogii wydaje się mieć odautorską sankcję i nie należy jej brać w żaden interpretacyjny nawias, pomimo tego (a może właśnie dlatego) że mit odrodzeńczy nie ma już tu znaczenia metaforycznego, ale staje się w powieści ziszczoną wiarą w reinkarnację bohaterów:

Wszyscy bohaterowie polegli gdziekolwiek i kiedykolwiek w sprawiedliwej walce, niezależnie od tego, w co wierzyli i jaką drogę odbyli potem w zaświatach - powrócą odrodzeni. Dlatego właśnie, że są bohaterami. Tyle razy, ile będzie potrzeba.

Tyranie nie mają szans (Bo, 356).

Nienaruszone zatem, waloryzowane dodatnio w prozie Lewandowskiego jest to, co stanowi centrum religii patriotyzmu: miłość ojczyzny, heroiczna śmierć za nią w walce „za naszą i waszą wolność” oraz wiara w romantyczny

${ }^{19}$ Należałoby się zastanowić, czy i w jakim stopniu autor żartuje sobie z polskiej megalomanii, gdy za sukcesem Japończyków pod Mukdenem kryje się geniusz polskiego artylerzysty. Jeżeli na poziomie zamysłu fabularnego dostrzec można zabieg ironii, to autor $\mathrm{z}$ całą powagą traktuje swoich bohaterów, gdy giną „,za wolność naszą i waszą”, do czego niżej powrócę.

${ }^{20} \mathrm{P}$. Tomczok, Opowiadanie historii Polski... 
mit odrodzeńczy (w oryginalnie sformułowaną tutaj palingenezę duchów) i wskrzeszenie ojczyzny przede wszystkim w sercu człowieka. Pisarz reaktywuje romantyczny mit.

Jak pisał autor biografii Lewandowskiego na jego stronie internetowej o jednym $\mathrm{z}$ bohaterów trylogii, któremu z braku miejsca nie mogę poświecić należytej uwagi:

Lewandowski chyba za główny punkt odniesienia dla człowieka uważa rodzinę oraz naród. W jego wizji pochodzenie determinuje losy człowieka: ktoś urodzony Polakiem ma obowiązki polskie i nie zazna szczęścia, dopóki tego nie zrozumie. Sergiusz Lawendowski, mimo że wychowany na Rosjanina, nie mógł pozostać lojalnym poddanym cara, jak chciał. Przynależność do narodu pozwala budować poczucie tożsamości oraz sensu w życiu ${ }^{21}$.

Łącząc konwencję popularnej powieści przygodowej z historią tak nieprawdopodobną, że noszącą znamiona historycznej alternatywy, Lewandowski pisze "ku pokrzepieniu serc"22.

\section{Wynalazki, światy równoległe i smutek polskiej historii}

W historiach alternatywnych dużą rolę w przestawieniu "zwrotnicy czasu" lub/i w przebiegu alternatywy historycznej odgrywają wynalazki techniczne. W Królowej Joannie d'Arc królowa Jadwiga ginie w zamachu, zasłaniając własnym ciałem swego syna. Skrytobójca strzela z bliskiej odległości z hakownicy bez haka - prototypu pistoletu, który w rzeczywistości w XV wieku nie istniał.

W Afgańskim Zeusie siłą napędową akcji ${ }^{23}$ jest poszukiwanie przez Sergiusza Lawendowskiego działającego gdzieś w Afganistanie „«nadajnika radiowego przyszłości», składającego się ze współpracujących razem hipotetycznego wzmacniacza i transformatora Tesli, który miał pełnić rolę «nadawczego obwodu antenowego»" (A, 62). Opisy urządzenia, zarówno w dyskusji przed wyprawą, jak i po jego odnalezieniu przez Sergiusza, obfitują w szczegóły naukowo-techniczne. Wynalazek wyprzedzający swoje czasy zostanie (niestety?) zagubiony, unicestwiony, nie zmieniając biegu historii.

Najciekawszą wersją historii alternatywnej z wynalazkiem wpływającym na bieg dziejów jest powieść fantastyczna w konwencji steampunkowej, czyli Orzeł bielszy niż gołębica.

Autor zadbał o prawdopodobieństwo powieściowego świata już przez samą edycję swego dzieła. W książce zamieszczone zostały szkice rzutów

\footnotetext{
${ }^{21}$ M. Smętek, Awanturnik...

${ }^{22} \mathrm{~W}$ nieco innym kontekście tak podsumowuje intencje pisarza Smętek - tamże.

${ }^{23}$ Kojarzącej się z filmami o Jamesie Bondzie.
} 
technicznych twardochodów Łukasiewicza, natomiast materiałem uzupełniającym tekst powieści jest dodatek formatu A3 w postaci rzekomego „Tygodnika Ilustrowanego" z dnia 22 stycznia 1864 roku z artykułem na temat sukcesu polskiej strategii i odparcia Moskali. Ryciny przedstawiają panią generał Emilię Plater oraz regenta Królestwa Polskiego Romualda Traugutta. Dopiero rewers gazety ujawnia prawdziwe kalendarium powstania styczniowego. Uwiarygodnieniu alternatywnej historii ma sprzyjać wydrukowany na papierze odmiennym od tego, na którym zamieszczono tekst książki, domniemany reprint polskojęzycznej wersji pisma „Le Monde Illustré" także z artykułem o "polskich machinach wojny". W powieści Orzet bielszy niż gotębica powstanie styczniowe już na samym początku odnosi sukcesy. Przestawiona została „zwrotnica czasu”.

Akcja dzieła rozgrywa się w 1866 roku i już od początku wiadomo, że wyzwolone przez Polaków tereny po trzech latach od wybuchu powstania nie sięgają nawet Białegostoku, na ziemiach zabranych ciągle wre partyzancka wojna, Austria i Prusy pozostają naszymi zaborcami, a Rosja bynajmniej nie pogodziła się z istnieniem wolnej Polski. Obeznanego z historią czytelnika nie zdziwi zatem, iż - jak w realnej historii - Polaków czekają "polskie Termopile", czemu nie zapobiegną techniczne osiągnięcia.

Jak nadmieniłam, ważną rolę w historii alternatywnej odgrywają cuda techniki. Ignacy Łukasiewicz $\mathrm{w}$ alternatywnej historii powstania styczniowego nie jest autorem lampy naftowej, ale „pędni, wielokroć mocniejszej od zwykłej maszyny parowej oraz procesu tenardyzacji” $(\mathrm{O}, 38)$. Innymi słowy: wymyślił silnik napędzany naftą do twardochodu, czyli prototypu pierwszego polskiego czołgu. Narrator informuje, że „nikt prócz samego Łukasiewicza nie umiał należycie wyrafinować procesu tenardyzacji, to jest wtrysku wody utlenionej do cylindra wypełnionego gorącą parą nafty, co pozwalało uzyskać spotęgowanie siły parcia na tłok" $(\mathrm{O}, 39)$. Termin "tenardyzacja" pochodził od nazwiska Louisa Thénarda, wynalazcy wody utlenionej, bo Łukasiewicz, mimo iż pomysł jej zastosowania był jego autorstwa, w swojej skromności postanowił poprzez nazwę procesu oddać hołd Francuzowi.

W alternatywnej historii styczniowej insurekcji postaci historyczne mają stereotypowe cechy pierwowzoru, Romuald Traugutt czy Józef Hauke-Bosak częściowo (do czasu przedstawionej alternatywnej historii) „zaopatrzeni są" w swoje autentyczne życiorysy - obaj są byłymi oficerami armii carskiej. Pojawiają się też postacie historyczne, o których wiemy mniej, ale ich znane z realnej historii zawody i role pozwalają snuć alternatywną nić biografii. Tak jest ze wspomnianym Łukasiewiczem czy Jamesem Clerkiem Maxwellem, autorem czterech równań elektrodynamiki klasycznej, który w powieści Lewandowskiego przybywa do Warszawy, by ofiarować swoje wsparcie Polakom. Jego zetknięcie z wprowadzonym na plan historii Danielem Teslą (nie Nikolą, ale jego bratem) ${ }^{24}$ doprowadzi do odkrycia, iż obok realnej rzeczywistości

${ }^{24}$ Wynalazca Nikola Tesla twierdził, że jego zmarły młodo brat był znacznie zdolniejszy od niego. Zdaniem Nikoli jego brat był „intelektualnym gigantem”, „uzdolnionym 
istnieje świat równoległy. Mamy tu do czynienia z „ciekawym przypadkiem tak zwanej alternatywnej historii alternatywnej, w której w alternatywnym świecie istnieją pogłoski o istnieniu świata alternatywnego, czyli naszego" ${ }^{25}$ :

Otóż z analizy równań Daniela wynika, że owa inna rzeczywistość może być światem niebywale podobnym do naszego i że znajduje się on całkiem blisko w przestrzeni fazowej drgań. Co więcej, można sądzić, że to również jest Polska, nazwijmy ją dla wygody i odróżnienia „obok-Polską”. Jeżeli pan dyktator się zgodzi, spróbuję nawiązać kontakt z tym równoległym Królestwem i poprosić tamtejszych patriotów o pomoc dla naszej sprawy $(\mathrm{O}, 178)$.

Kontakt z historyczną Polską - dla bohaterów z ich alternatywną rzeczywistością - ujawnia tragiczną prawdę, iż z "obok-Polski” nie można spodziewać się militarnej pomocy, gdyż w tamtejszym świecie powstanie przegrywa. Co istotne - wynaleziona pianola Maxwella pozwala nie tylko na przeniesienie się $\mathrm{w}$ równoległy byt, ale także - $\mathrm{w}$ równoległą przyszłość. Przyniesienie $\mathrm{z}$ tej przyszłości historycznego artefaktu stanowi dla bohaterów powieści potwierdzenie klęski powstania i śmierci Traugutta na stokach cytadeli w "obok-Polsce”. Opowiadana "niebyła" historia powstania styczniowego i lat bezpośrednio po nim w powieści Orzeł bielszy niż gotębica zakończy się tym, iż bohaterowie zdecydują o przeniesieniu się do równoległej owej „obok-Polski”, w której dopełnią się ich potwierdzone faktografią losy. Dlaczego dokonają takiego wyboru?

Otóż wyraźniej niż w poprzednich powieściach problematyka etycznej odpowiedzialności człowieka za swoje wybory i za historię staje się elementem dyskursu, ważkim składnikiem kształtującym fabułę dzieła. Lewandowski pokazuje, iż na nic zdają się wynalazki techniczne, twardochody, lekkokochody, jeżeli zawiodą ludzie i ich moralność. W powieści projekt twardochodu zostaje wykradziony i przekazany Rosjanom. Chociaż Polacy będą w stanie pokonać wyprodukowaną przez wrogów większą i skuteczniejszą od ich pojazdów machinę, bitwa, w której to się dokonana, także w tej historycznej alternatywie zyska miano "polskich Termopil”. Polacy nie będą w stanie dalej z powodzeniem toczyć wojny, której zakończenie może być tylko tragiczne.

To ludzie, a nie ich wynalazki odpowiadają bowiem - zdaniem autora - za kształt historii. Lewandowski kreuje rodzaj historycznej biografii à rebours, czyniąc odpowiedzialną za zdradę Elizę Łupińską, w której życiorysie rozpoznajemy szczegóły życia Elizy Orzeszkowej. Pisarz jakby nie ośmiela się ze względu na "czarny pijar" uczynić zdrajczynią pisarki pod jej historycznym nazwiskiem. Zdrady dokonuje ona z powodu swej pychy i słabości. Ciesząca się popularnością, wedle Emilii Plater jednak wątpliwej wielkości,

w nadzwyczajnym stopniu". Cyt. za: https://pl.wikipedia.org/wiki/Nikola_Tesla (dostęp: 14.06. 2017). Na tej przesłance na temat brata Nikoli Tesli najwyraźniej bazuje Lewandowski.

${ }^{25}$ Historia alternatywna, [w:] Stownik rodzajów..., s. 381. 
pisarka obawia się kompromitacji, gdy Rosjanie ujawnią jej sekret, że jest ona... lesbijką.

Karkołomne przetworzenie życiorysu pozostałoby tylko dla wielu niesmacznym pomysłem, a szantaż z tego powodu elementem political fiction, gdyby nie skomplikowanie tego homoerotycznego wątku. Otóż Emilia Plater także jest lesbijką, ale ta cecha osobowości w jej przypadku nie może stać się źródłem politycznego szantażu.

Tak, mam upodobanie do własnej płci, ale nadal jestem dziewicą. Nietkniętą ani od mężczyzny, ani i od kobiety. [...] Wstrzymałam się i nie pofolgowałam sobie nigdy, bo taka rzecz wydałaby się prędzej czy później, a wtedy całe dzieło mojego życia poszłoby w niwecz, wybrałam więc to, co ważniejsze. Polska jest moją jedyną kochanką! (O, 207).

Lewandowski stosuje tu strategię skandalu, nie tylko czyniąc historyczną postać lesbijką. Emilia Plater jako przywódczyni sztyletniczek w okrutny sposób każe zamordować bez sądu Łupińską, odmawiając na dodatek pisarce prawa do przedśmiertnej spowiedzi. Nie wydaje się jednak, że rzecz idzie tylko o żart, kpinę z LGBT i obecności wątków homoerotycznych w literaturze. Wymowa powieści jest czytelna: polityczny szantaż grozi tym osobom publicznym, które nie zachowują porządku moralnego. Konsekwencje takiego szantażu są groźne dla Polski. Poruszając problematykę etycznej odpowiedzialności za działalność publiczną, działanie mające siłę sprawczą w historii, pisarz uprawia rodzaj dydaktyzmu. Dydaktyzm ten znajduje swoją syntezę w romantycznym przesłaniu „Polska jest moją jedyną kochanką". Bohaterem, autorytetem może zostać ten, dla kogo Polska jak w tej powieści pozostaje wartością nadrzędną wobec ludzkiej miłości (wątku tego z braku miejsca nie rozwijałam) i ludzkiego marzenia o sławie. Rola wynalazków, wędrówka między światami - to tylko elementy poetyki gatunku służebne wobec dydaktyzmu, wobec zawartej w dziele problematyki etycznej.

Na koniec warto zwrócić uwagę na jeszcze jeden wymiar dydaktyzmu Lewandowskiego. Omawianą powieść należałoby czytać w kontekście nurtu literatury podejmującej dywagacje na temat sensu powstań narodowych. Pisałam wyżej, że w dziele tym mamy do czynienia z zabiegiem ukazania alternatywy historii alternatywnej. Spróbuję krótko to spostrzeżenie rozwinąć. Jeśli potraktować prezentowaną alternatywę powstania styczniowego i jej alternatywę, czyli naszą historię styczniowej insurekcji, nie jako sekwencję historycznych i powieściowych zdarzeń, ale jako dwie wersje point of divergence polskiej historii, to możemy stwierdzić, że podobnie jak historyków Lewandowskiego zajmuje kontrfaktyczność historii. Możemy także po lekturze powieści postawić za nim pytanie: co by się stało, gdyby powstanie zakończyło się zwycięstwem? Co mogłoby do tego sukcesu doprowadzić - bardziej geniusz myśli technicznej czy wierność ideałom i samemu sobie? Może to pytanie nienowe, ale też $\mathrm{w}$ tej odmianie prozy popularnej historia alternatywna chce pozostać nauczycielką życia. 


\section{B I BLIOGR AFIA}

Lewandowski K.T., Afgański Zeus. Powieść przygodowa, Wrocław 2011.

Lewandowski K.T., Bohaterowie się odradzaja. Powieść przygodowa, Wrocław 2012. Lewandowski K.T., Bursztynowe Królestwo. Powieść przygodowa, Wrocław 2009. Lewandowski K.T., Królowa Joanna d'Arc. Powieść fantastyczna, Warszawa 2000.

Lewandowski K.T., Orzeł bielszy niż gotębica (powieść fantastyczna w konwencji steampunk), Warszawa 2013.

Lewandowski K.T., Rzemieślnik metafizyk [rozm. P. Dunin-Wąsowicz], [online] http://ksiazki.onet.pl/rzemneslnik-metafizyk/x078z (dostęp: 25.08.2016).

Tierling-Śledź E., Powstanie styczniowe, którego nie było, czyli historia alternatywna w powieści Adama Przechrzty "Gambit Wielopolskiego", [w:] Dyskurs powstańczy w kulturze polskiej, red. D. Dąbrowska, Szczecin 2015, s. 129-146.

Tomczok P., Opowiadanie historii Polski - całkiem inaczej, "artPapier" 2009, nr 14, [online] http://artpapier.com/index.php?page=artykul\&wydanie $=88 \&$ artykul=2034 (dostęp: 5.08.2016).

Węcławiak T., Historia historii nierówna - kilka uwag o definicji historii alternatywnej, „Podteksty. Czasopismo kulturalno-naukowe” 2007, nr 4, [online] http:/ / podteksty.amu.edu.pl/podteksty / ?action=dynamic\&nr=11\&dzial=4\&id=254 (dostęp: 5.08.2016).

\section{STRESZCZENIE}

Autorka artykułu wyraża przekonanie, iż na przełomie XX i XXI wieku wzrosło zainteresowanie odmianami literatury popularnej, w tym historią alternatywną. Po przypomnieniu rozróżnień terminologicznych pomiędzy historią alternatywną i historią kontrfaktyczną przystępuje ona do omówienia historii alternatywnych Konrada T. Lewandowskiego. Badaczka dochodzi do wniosku, że w książkach Konrada Lewandowskiego historia alternatywna, pełniąc funkcję ludyczną, nie przestaje być nauczycielką życia.

\section{Słowa kluczowe}

historia alternatywna, historia przeciwstawna, historia kontrfaktyczna, historia wirtualna, Konrad T. Lewandowski

\section{SUMMARY}

\section{Konrad T. Lewandowski's Alternative Histories}

The author of the article is of the opinion that at the turn of the $20^{\text {th }}$ and $21^{\text {st }}$ centuries there was a growing interest in various types of popular literature, including 
alternative history. Upon reminding us of the terminological differences between alternative (alternate) history and counterfactual (virtual) history, she goes on to discuss alternative histories by Konrad T. Lewandowski and concludes that in his books, while playing an entertaining role, alternative history still remains the teacher of life.

\section{Keywords}

alternative history, alternate history, counterfactual history, virtual history, Konrad T. Lewandowski 